\title{
Interaction Between Public Authorities and Stakeholders in Social Media (Comparative Analysis of the Regional Practician)
}

\section{V.V. Zotov and A.V. Gubanov}

Southwest State University, Kursk, Russian Federation

\section{Abstract}

The wide functionality of social media allows the authorities of the territorial subject to choose a variety of models for using this information resource for organizing interaction in the space of public communications. The purpose of the present research is to explore the practice of public authorities organizing interaction with stakeholders in social media. The study took into consideration official accounts of regional state and municipal structures, as well as regional accounts of federal executive authorities in social networks "Vkontakte", "Odnoklassniki", Facebook, Instagram and Twitter. The analysis has shown that in the median region, the number of government accounts is

Corresponding Author: V.V. Zotov

om_zotova@mail.ru

Published: 21 January 2021

Publishing services provided by Knowledge E

(c) V.V. Zotov and A.V.

Gubanov. This article is distributed under the terms of the Creative Commons

Attribution License, which permits unrestricted use and redistribution provided that the original author and source are credited.

Selection and Peer-review under the responsibility of the XXIII International Conference Conference Committee.

\section{G OPEN ACCESS} almost twice as high as the social network "Vkontakte", while the structure of official accounts of Moscow authorities is more differentiated by social networks. Despite a 10-fold increase in the number of Muscovites over residents of the Kursk region, the share of subscribers to official government accounts in them among the General population is comparable. The intensity of the use of feedback forms for official accounts of the authorities of the Kursk region exceeds similar indicators of Moscow city. But at the same time, the publication activity of official accounts the Kursk region authorities is lower than in Moscow.

Keywords: public administration, regional governance, public communications, social media, stakeholders.

\section{Introduction}

The development of information and communication technologies has led to a gradual transformation of the space of public communications as a place for discussion and coordination of positions on worthwhile cause. In a relatively short period of time, modern media make it possible to bring local information to the level of the largest international mass media and bring it to a wide range of Internet users. Social media (or more traditionally - social networks) occupy a significant position among these channels. In its history, social networks have gone from communication services to complex multifunctional platforms with a friendly interface at the same time. The main 
practical result of this process is their demand among the widest possible range of citizens.

The growing importance of network practices, in turn, has a direct impact on the activities of public administration bodies, updating scientific research in this direction $[5,6,8]$. Interaction between authorities and stakeholders in social media requires the greatest scientific attention. Hence the purpose of the study is to analyze the experience of organizing interaction with stakeholders in social media by public authorities.

\section{Methodology and Methods}

In order to achieve this purpose, a comprehensive study of the public administration bodies' activities in social media in the territory of the city of Moscow and the Kursk region was carried out. These subjects of the Russian Federation were selected by indicators of informatization and development of the information society respectively as the leader and median region $[2,3,7]$. The analysis was carried out over a fixed period of time (January-February 2020). The study took into consideration official accounts of regional state and municipal structures, as well as regional accounts of federal executive authorities in social networks "Vkontakte", "Odnoklassniki", Facebook, Instagram and Twitter. Personal accounts belonging to regional heads and other high-ranking officials were not analyzed.

\section{Results and Discussion}

In total, 409 accounts were identified during monitoring, 241 of which relate to government agencies in Moscow and 168 to Kursk region. A detailed analysis of the collected database has revealed a significant prevalence of regional government accounts (180 - Moscow; 141 - Kursk Region). The representation of regional accounts of federal structures was about 3 times less. The detailed statistics are shown in Figure 1.

The distribution of official accounts depending on the specific social network is indicative in terms of network practices of users and the folded features of communication channels between them and government agencies. Thus, in the median region almost with a double advantage leads the social network "Vkontakte". 63\% of all official accounts are registered here. In second place is "Odnoklassniki" (12\%). Instagram, Facebook and Twitter were almost identical at 8-9\%. A completely different trend was revealed in the structure of official accounts in Moscow. VKontakte and Facebook resources ( $27 \%$ and $26 \%$ respectively) gained leadership with a slight difference, 


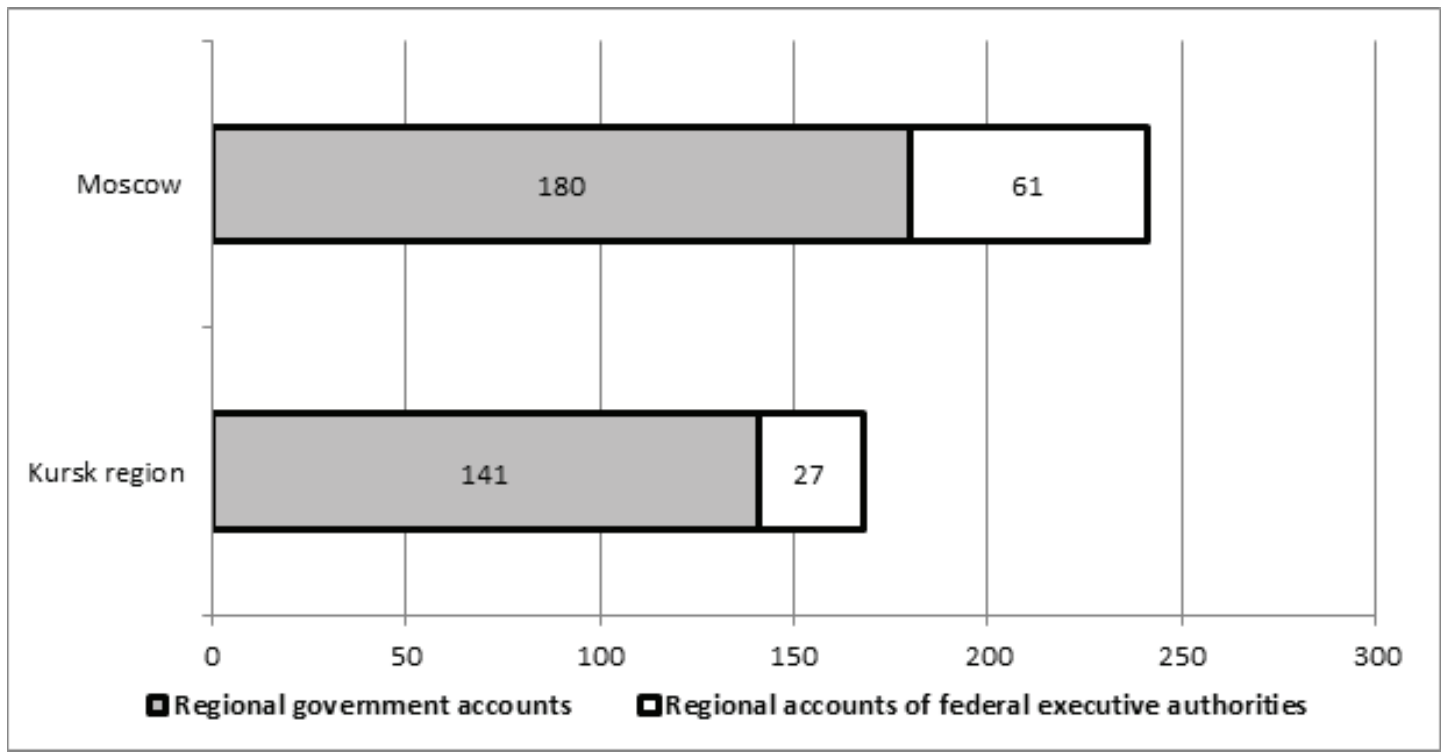

Figure 1: Comparison of the number of official accounts of the executive authorities of the Kursk region and Moscow

followed by Twitter (24\%), Instagram (17\%) and Classmates (7\%). Detailed statistics are shown in Figure 2.
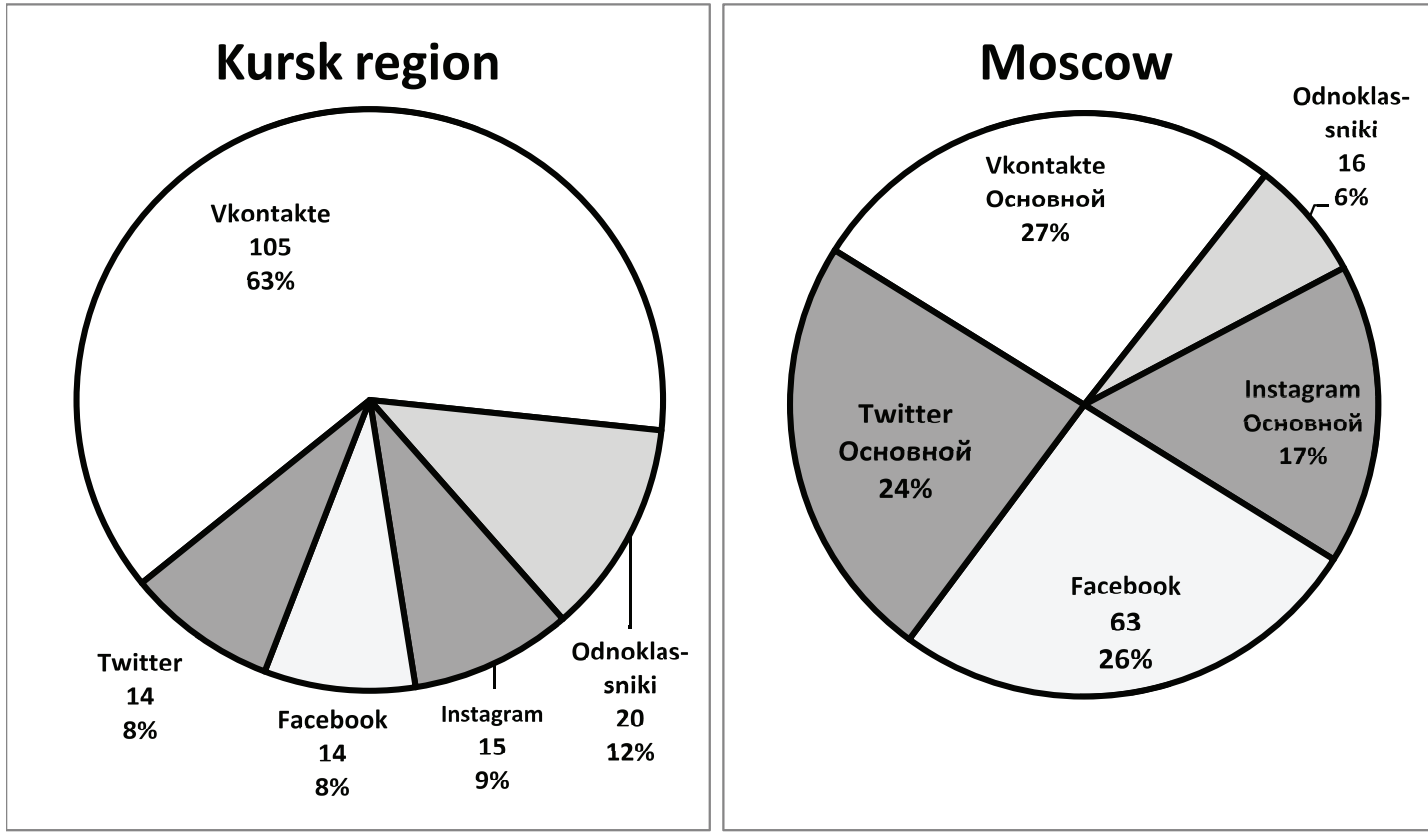

Figure 2: Distribution of official accounts of executive authorities across different social networks.

The data obtained may indicate a number of significant differences. Firstly, the equal presence of the capital's government bodies in various social networks at once testifies to openness to dialogue and readiness to build a direct dialogue with citizens. Secondly, the presence of developed accounts at one government structure in several social networks implies the availability of qualified specialists with the necessary skills to 
carry out orderly and systematic work in them, because almost every network platform created has a specific set of tools for interaction with stakeholders (from ordinary citizens to large organized communities).

The results of the analysis are influenced by the factor of uneven geographical distribution of the different social networks audience According to the estimates of experts from the center "Brand Analytics," as of January 2020 the average level of penetration of social network "VKontakte" among users who published at least 1 post in the account of a government authority for an equal amount of time, amounted to 32.2\% for Moscow and 21.7\% for Kursk. Facebook indicators amounted to $7.3 \%$ for Moscow and only $0.5 \%$ for the Kursk region, for the microblogging service Twitter $1.5 \%$ and $0.2 \%$, respectively. A special case is the social network "Odnoklassniki", which accumulated one of the largest RuNet audiences, but did not occupy a leading position in the representation of government agencies in each of the studied regions. Here the situation for both regions is equally bad [1].

When analyzing the social network interaction between the authorities of the Russian Federation's constituent entities and stakeholders, it should be noted that there is a significant disparity between the studied regions in the number of subscribers, which directly follows from the overall difference in the number of residents. The total number of accounts of the direct authorities of Moscow is 3055 thousand (of which 2,824,000 subscribers of the authorities of the constituent region and 231,000 - federal authorities operating on the territory of the constituent region). The situation for the Kursk region is as follows: the general audience of government bodies is 233 thousand subscribers, of which 197,000 are subscribers of state and municipal authorities of the Kursk region and 34,000 are regional structures of federal authorities. For an objective comparison of the data, they are reduced to the total population of the constituent entities of the Russian Federation, which, according to the Federal State Statistics Service, is $12,615,882$ for Moscow and 1,103,059 for the Kursk region. The results of the comparison are shown in Figure 3.

Most popular network platforms in Russia are effective not only for unilateral replication of content, but also in organizing direct channels of communication between citizens and officials. A direct reflection of the social networks users' interest in the publication activity of the governing bodies of the Russian Federation subject is the presence of feedback, expressed in setting likes / dislikes, commenting on publications or carrying out repost [4]

The results of the study has shown a significant superiority of official accounts of Moscow state structures in the total number of user reactions, the number of likes 


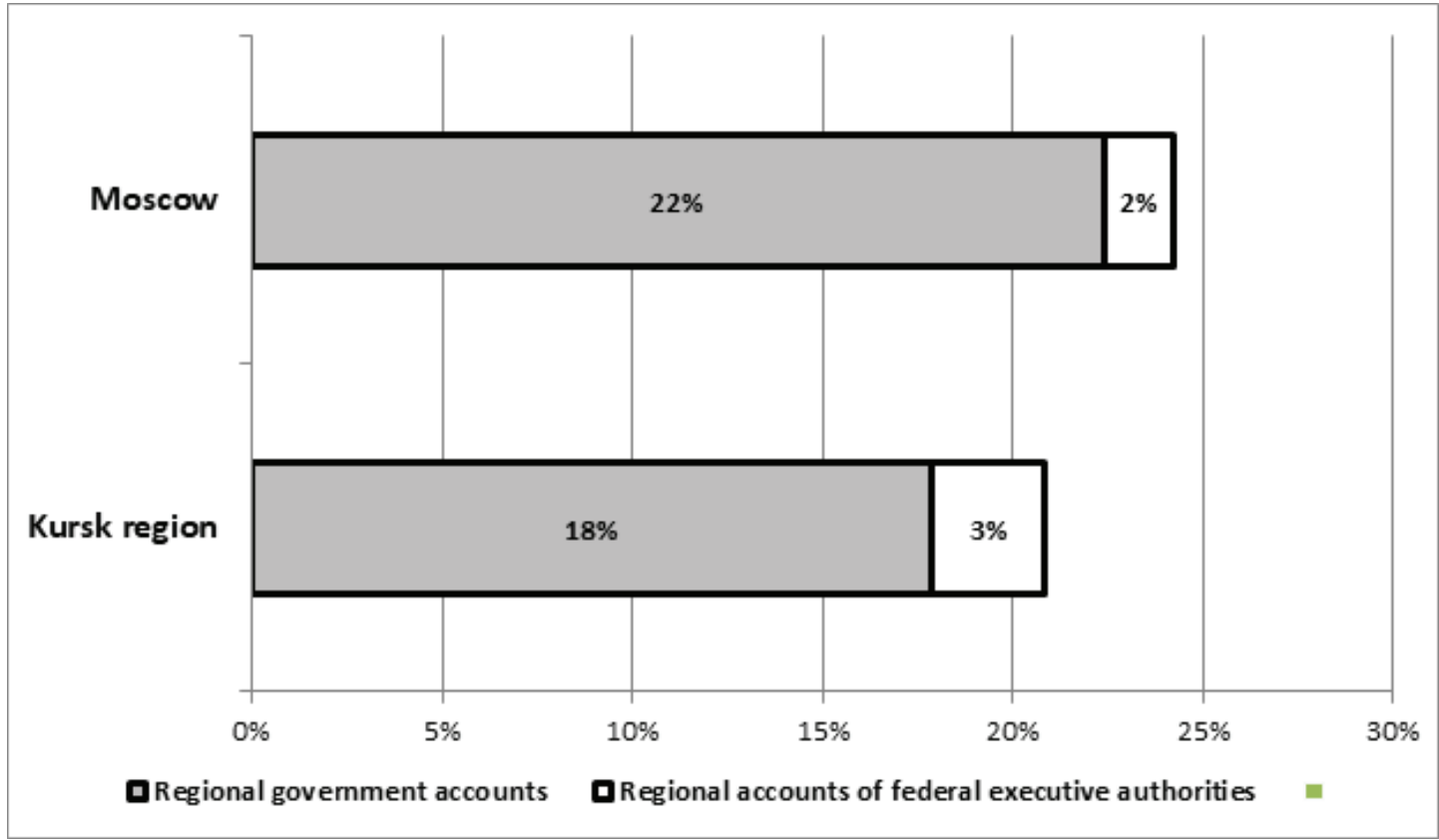

Figure 3: Distribution of the audience of official accounts of executive authorities of Kursk region and Moscow in \% of the total population.

and repost in absolute values (For Moscow there were 576,132 response reactions in accounts, and for Kursk region - 216,681). At the same time, the accounts of authorities of the Kursk region turned out to be leaders in terms of commenting on publications in absolute terms. Detailed statistics are presented in Figure 6.

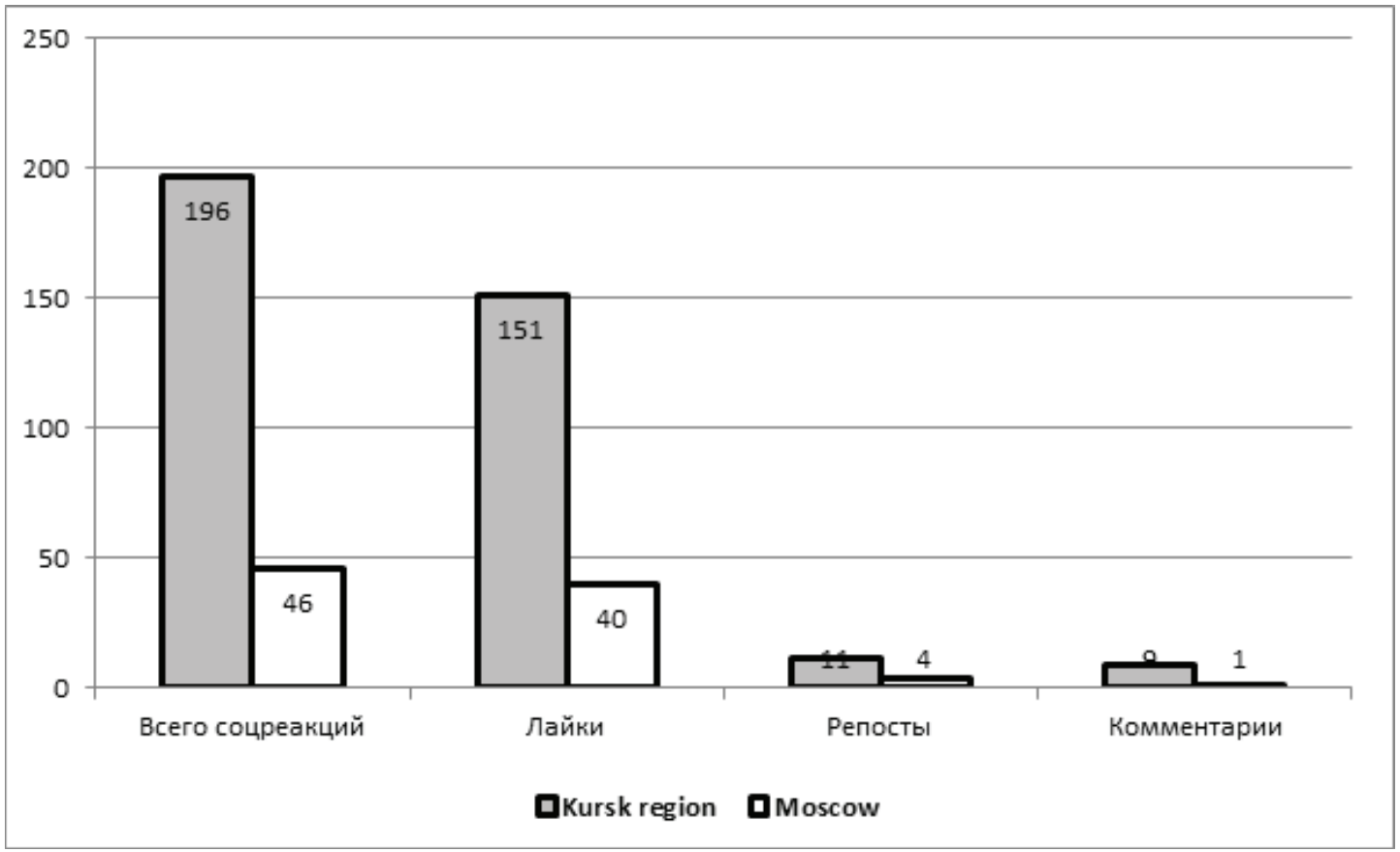

Figure 4: Comparison of the intensity of use of feedback forms for official accounts of authorities of the Kursk region and the city of Moscow (\%o). 
The authorities' publication activity has a direct impact on the final distribution of these results. In our view, the question of choosing the optimal level of average daily and average monthly number of publications for executive authorities is one of the most difficult. The analysis of the generated publications has revealed the predominance of specialized content directly related to the specifics of a particular regional or municipal government structure activity. Often, such material contains reports, regulations, and other highly targeted information, for which full adaptation to the social media format is difficult. The presence of a large number of such publications in user tapes is necessarily accompanied by an increase in negative reaction. However, in the case of a general decrease in publication activity, there will be a general decline in target audience coverage, and eventually citizens may simply not notice the content in the fast-changing news feed.

The scoring results have indicated a relatively greater activity in the social media of the state structures of Moscow city. The most active accounts post an average of about 10 posts per month, while the least active ones post up to 5 unique posts per month. It is also important to note the steady trend of increasing the amount of content completely recycled or generated directly to the specifics of social media. A number of accounts are actively circulating infographics and videos in the currently popular 60-second digest format. Detailed statistics of publication activity are shown in Figure 5.

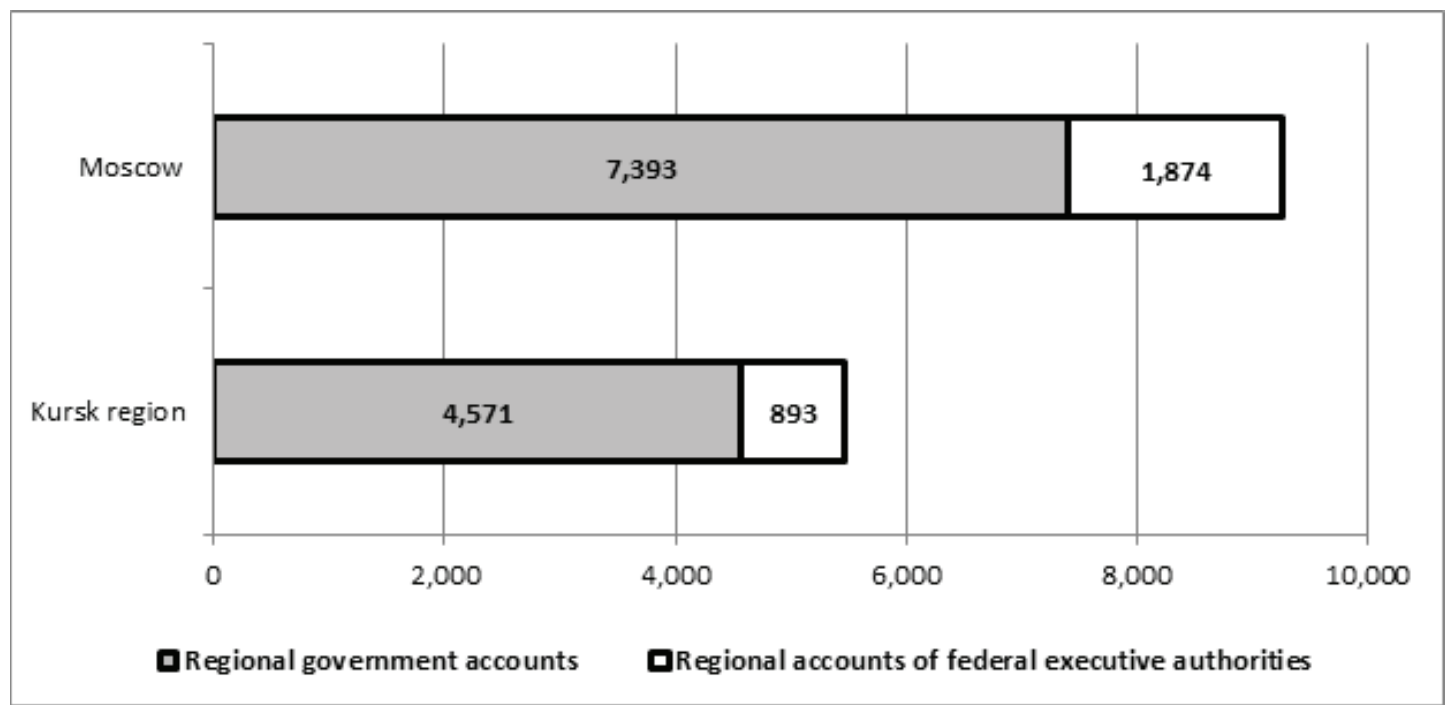

Figure 5: Publication activity of official accounts of executive authorities of the Kursk region and the city of Moscow (number of publications).

One of the most important indicators directly reflecting interaction between officials and stakeholders in social media is the level of commutability of replicated publications. At the same time, citizens discuss directly published material in the comments, as well as often make constructive proposals there or post their own appeals to the authorities. 
They do the last of the above when they were unable to get a proper response through the private messaging service.

It is important to note that the facts of direct restriction or total prohibition of users commenting on posted publications were recorded in a number of official accounts. In our view, in this case, officials directly refuse direct contact with citizens, turning to purely unilateral administrative methods of replication of information. The issue of restrictions on comments was therefore both professional and ethical.

The study of the network space allows us to identify in each of the regions government structures for which accounts have caused the largest number of discussions among users of social networks.

TABLE 1: Most popular accounts of public agency of the constituent region

\begin{tabular}{|c|c|}
\hline Kursk region & Moscow \\
\hline 1. Administrations of Kursk region. & 1. Moscow government. \\
\hline 2. Administration of Kursk. & $\begin{array}{l}\text { 2. Department of education and science of } \\
\text { Moscow. }\end{array}$ \\
\hline $\begin{array}{l}\text { 3. Committee of Transport and Roads of the } \\
\text { Kursk Region. }\end{array}$ & $\begin{array}{l}\text { 3. Department of entrepreneurship and } \\
\text { innovative development of Moscow. }\end{array}$ \\
\hline $\begin{array}{l}\text { 4. Committee of Youth Policy and Tourism of } \\
\text { the Kursk Region. }\end{array}$ & 4. Moscow Culture Department. \\
\hline $\begin{array}{l}\text { 5. Committee of Social Welfare, Motherhood } \\
\text { and Childhood of the Kursk Region. }\end{array}$ & 5. Moscow Healthcare Department \\
\hline
\end{tabular}

\section{Conclusions}

The analysis of the practices involving social media authorities of the city of Moscow, as the leading region on indicators of informatization and development of the information society, and the Kursk region, as the median region on these indicators, allows us to conclude the following. In the median region, the social network "Vkontakte" leads almost with a double advantage in the representation of authorities' official accounts, while the structure of official accounts of Moscow authorities is more differentiated by social networks. Despite 10 times the number of residents of Moscow over residents of the Kursk region, the share of the population that is subscribers of official accounts of the Kursk region and Moscow authorities as a whole is comparable. But the intensity of the use of feedback forms for official accounts of the authorities of the Kursk region exceeds similar indicators of the Moscow city but at the same time, the publication activity of official accounts of the authorities of the Kursk region is lower than in Moscow. Despite the difference between the regions, the established network practices of interaction with stakeholders proved to be similar in many ways, which creates the necessary 
conditions for the unification of approaches to social network management of public communications and, accordingly, the legal framework for the use of social media by officials.

\section{Funding}

The reported study was funded by RFBR, project number 20-011-00694 «Public Administration as Configuring of Relational Networks in the Public Space of a Digital Society»

\section{References}

[1] Brand Analytics. (2020). Statistics of social networks. Retrieved January 31, 2020 from https://br-analytics.ru/statistics/am/?hub_id=3\&date=202001\&period_type= month

[2] CNews. (2019). ICT in the public sector. Retrieved January 29, 2020 from https: //www.cnews.ru/reviews/ikt_v_gossektore_2019

[3] D-russia.ru (Digital Russia). (2017). MinComSvyaz presented the rating of Informatization of regions-2017. Retrieved January 29, 2020 from http://d-russia.ru/ minkomsvyazpredstavila-rejting-informatizatsii-regionov-2017.html

[4] Gubanov, A. V. and Zotov, V. V. (2019). Social networks as a new tool of state and municipal management in the Russian Federation. Communicology (Russia), vol. 5, issue 4, pp. 83-92.

[5] Gubanov, A. V., Zotov, V. V. and Anciferova, I. V. (2017). Social Network in the System of Public Administration of the Russian Federation. In: Proceedings of the 4th International Multidisciplinary Scientific Conference on Social Sciences and Arts SGEM, book 4, vol. 1, pp. 245-252.

[6] Kiseleva, A. M. and Shpak, E. A. (2015). Social networks in the process of communication of the authorities and society. Management Issues: ScientificInformation Journal, vol. 6, issue 18, pp. 66-75.

[7] Ministry of Digital Development, Communications and Mass Media of the Russian Federation. (2019). Monitoring of regional Informatization. Retrieved January 29, 2020 from https://digital.gov.ru/ru/activity/directions/783/.

[8] Startsev, A. A. and Grishanin, N. V. (2018). Social networks in the process of communication between the government and society. Communicology (Russia), vol. 6, issue 5, pp. 108-119. 